\title{
A FRAMEWORK TO DESIGN MASCOT CHARACTER AS SUPPORTING TOOL FOR CITY BRANDING BASED ON YURU-CHARA CONCEPT
}

\author{
Triyadi Guntur Wiratmo ${ }^{1}$, Banung Grahita ${ }^{2}$, Riama Maslan ${ }^{3}$, Fadillah ${ }^{4}$, Dianing Ratri ${ }^{5}$ \\ $1,2,3,4,5$ Program Studi Desain Komunikasi Visual, Fakultas Seni Rupa dan Desain, \\ Institut Teknologi Bandung \\ triyadiguntur@gmail.com ${ }^{1}$, banung.grahita@gmail.com²
}

\begin{abstract}
Abstrak
Pemanfaatan maskot, yang juga disebut "Yuru-chara", untuk place branding. adalah hal yang biasa dilakukan di Jepang. Dalam beberapa kasus, seperti Kumamon yang digunakan sebagai maskot kota Kumamoto, terbukti sukses. Beberapa tahun terakhir kota-kota di Indonesia seperti Surabaya, Malang, dan Balikpapan telah mencoba menggunakan maskot dalam membentuk citra kotanya. Meski demikian, sebagian besar maskot tersebut tidak diterima dengan baik oleh masyarakat. Penelitian ini bertujuan untuk menemukan kerangka kerja praktis dalam merancang maskot yang efektif untuk city branding yang menarik bagi publik dan merepresentasikan kota dengan baik. Framework tersebut dibuat dengan mengadopsi pendekatan desain yang digunakan untuk mendesain Yuru-chara di Jepang dengan menggunakan Metodologi Penelitian Desain. Hasilnya, kerangka kerja desain yang terdiri dari empat tahap, yaitu 1) menentukan pesan, (2) membuat penamaan, (3) mendesain, (4) menciptakan dan memelihara visibilitas dapat dikembangkan. Berdasarkan evaluasi yang dilakukan oleh para desainer dan ahli, ditemukan bahwa framework tersebut dapat dimengerti dan berguna untuk menciptakan desain maskot yang menarik, tetapi memiliki kelemahan untuk memenuhi tujuan city branding. Sebagai rekomendasi, perlu ditambahkan tahapan penelitian yang mendalam sebagai proses pendefinisian pesan yang digunakan sebagai dasar ide desain.
\end{abstract}

Kata Kunci: yuruchara, desain maskot, desain karakter, city branding, metode desain

\begin{abstract}
The utilization of a mascot called "Yuru-chara" for place branding is a common practice in Japan. In several cases, for instance, Kumamon, the mascot of Kumamoto city proven to be successful. In recent years, cities in Indonesia such as Surabaya, Malang, and Balikpapan have tried to use mascots in their city branding. Nevertheless, most of the mascots are not well-received by the public. This research intends to find a practical framework to design an effective mascot for city branding that is appealing to the public and properly represents the city. The framework is created by adopting the design approach that is used for designing Yuru-chara in Japan, using Design Research Methodology. As a result, a design framework that consists of four phases, which are 1) specifying message, (2) creating naming, (3) designing, (4) creating and maintaining visibility to developed. Based on the evaluation performed by designers and experts, it is discovered that the framework is understandable and useful for creating appealing mascot design, but has a weakness to fulfill the city branding purpose. As a recommendation, an in-depth research phase needs to be added as a process for defining the message used for the basis of the design idea.
\end{abstract}

Keywords: yuru-chara, mascot design, character design, city branding, design method 


\section{INTRODUCTION}

Utilization of mascot as supporting tool for place branding, which includes nation, region or city branding, in Japan has been a common practice. Kumamon a mascot character of Kumamoto city, Funashi of Funabashi city, Unari-kun of Narita city and Hikonyan of Hikone castle are some examples that show how mascot could be very useful for a city branding campaign. As Instance, Kumamon had been a key factor in the success of Kumamoto city branding. Kumamon character have significant impact for increasing tourism expenditures in Kumamoto city since 2011 (Soltani et al., 2017). Based our research in Indonesia, from 2018 to 2019, it is known that several cities in Indonesia such Surabaya, Semarang, Malang, and Balikpapan have tried to use mascot in their branding effort. Until now, only Malang and Surabaya Mascot is well designed. Nevertheless, they are not popular among their own citizen and do not have significant contribution to their city branding. Seeing the popularity and succeed of Yuru-chara such as Kumamon and Funashi, this research tries to understand Yuru-chara design concept and try to develop a framework for designing mascot for city branding based on that concept.

\subsection{Principle of Mascot Design}

Mascot design could be considered as a branch of character design that focusing on communicating or representing some entities, such as brand, place, services, etc. The term "mascot" is derived from the French word "mascotte" that means charm or luck. Before 19th century this term referred to inanimate object such as lock of hair or wooden figure on sailing ship that use to bring a good luck. This concept was adopted by military and sports club in 20th century by using live animal as their mascot to give luck and spirit to their squad, the live animal then replaces by a two-dimensional character. In more recent development, the character is made as costume character so it could do direct interaction with people, this concept is argued to be more engaging for its audiences.

Based on this description there are two important aspect in a mascot design. First is an intangible aspect, it is value, spirit or personality and the second is a tangible aspect, it is an appealing visual design that represent them. In addition, due the need for maintaining engagement with audience, today the mascot must have a physical/ threedimensional form, usually in the form of costume character.

\subsection{Principle of Yuru-chara Design}

a) Idea

Yuru-chara could be considered as one of mascot design approach in Japan. The manner of Yuru-chara design come from the word "Yurui" which in general means loose, but in this context, it also has several connotations such as gentle, weak, or laidback. The term of Yuru-chara is coined by Jun Miura an illustrator, and cultural critic in 2000 (Occhi, 2010). Statement by Miura about three characteristics of a Yuruchara design: it should deliver a strong love message to hometown or local areas, movement or behavior of the character should be unique, unstable, also awkward and the shape of the character should be unsophisticated, relax, and fun (Suter, 
2016). The statement from Miura explains the fact found from the observation that the Yuru-chara design often seems to be naive, and sometimes oversimplifying the entity that it represents. However, it is also proven during the observation, these typical qualities make the design unique and has its own attractiveness for the public in Japan. According information gathered from Mitsuru Sugaya during the interview, the Yuru-chara naïve appearance is a result from wordplay that often used as basic for their design idea. The Yuru-chara design begin with a naming which is then translated into visual. For the naming, designer plays with combination of two or more words that represent ideas about their city or local area. Often, the words are crossed in their mind spontaneously without a deep research. It results a bizarre word combination which is when translated into a design, it makes the design seems naïve but also unique. Naming of Yuru-chara that is distinctive and pleasant to hear, also play significant role for its popularity (Nakasato \& Tanaka, 2017).

b) Design

It is found that the concept of Yuru-chara intend to build an engaging experience between brand/ entities and its audiences. To meet this goal, based on analyses and interview with the expert, it is known that there are several design aspects were considered in the design process, those are: shape, color and material, movement, and sound.

\section{Shape and proportion}

Based on visual data gathered from the field study, for translating the 'Yurui' manner, there are several typical shapes could be seen in Yuru-chara design (see Fig.1): the overall character shape is simplified, there is lack of detail or realism; most of the character have a rounded/ edgeless shape for all of the body parts; as general rules, the proportion is no more than 3 heads tall; the head is bigger or at the same size with the body; the body tend to be in a babylike shape with short limb and fat belly and there are some emphasize on the shape that represent the wordplay as the basic idea for the design.
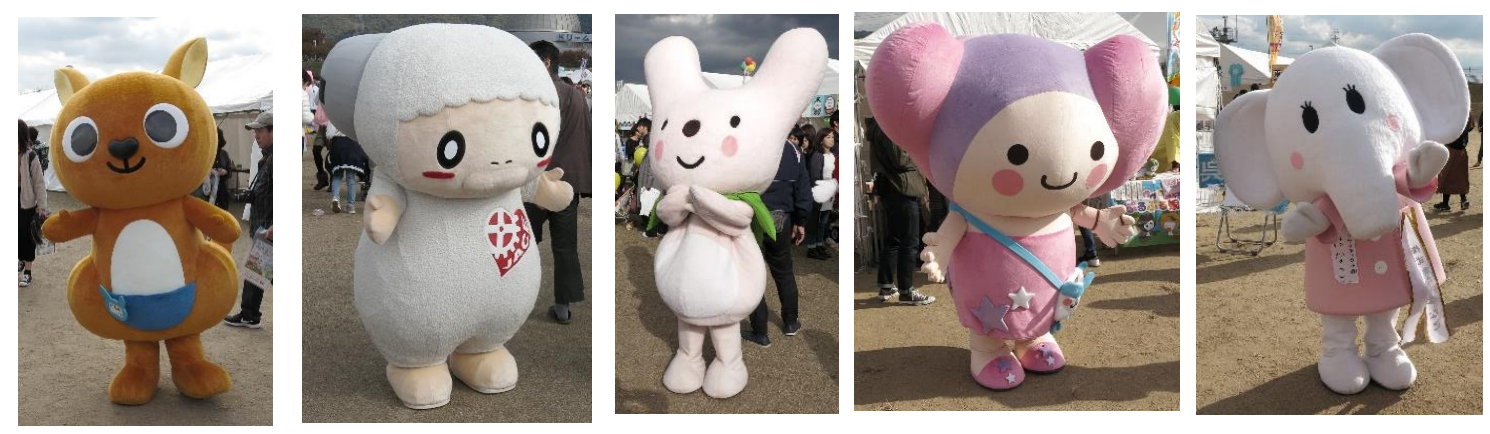

Figure 1 Typical shape of Yuru-chara Character [Source: author's documentation]

Aside from those typical shapes, according to the expert interview, in designing Yuruchara it is important for designer to accommodate human structure through the shape of the character since it has to be made as a costume character. Surely, it should be done without violating the 'Yurui' manner. 


\section{Material}

Since Yuru-chara will interact physically with the audience, it is important to consider tactile aspect of the design. On the physical world, tactile or touch could trigger certain affective/ emotional response (Sakamoto, 2017). Therefore, material used to make the costume should be selected carefully. There are two kinds of material found during the field study. First, the costume made of fabric stuffed by soft material such as cotton or similar kind of material, some of them has fur attached on the outside. Second, the costume made of balloon material with or without inside structure filled by air, this type of costume has shiny and smooth texture. Both of these materials are soft and give a pleasing or comfortable feeling when touched. By using these kinds of material, the Yuru-chara also seems wobbly and unstable.

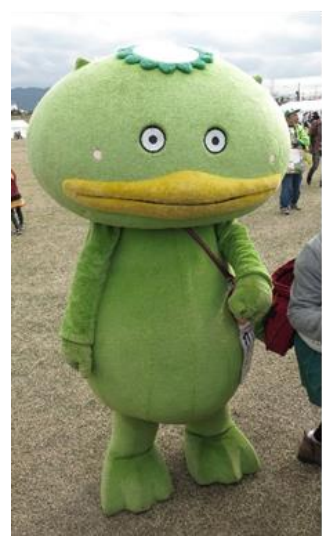

(a)

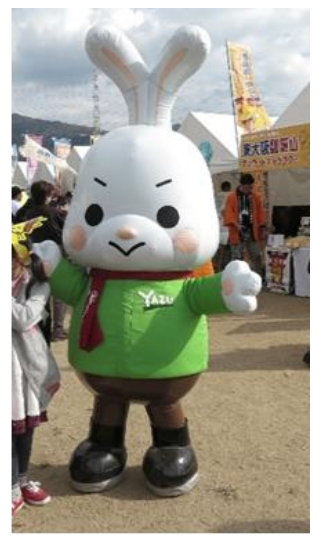

(b)

Figure 2 (a) Yuru-cara costume made of soft fabric, (b) Yuru-chara costume made of balloon material. [Source: author's documentation]

\section{Movement}

As stated before, according to Miura movement or behavior of the Yuru-chara should be unique, unstable, and awkward (Occhi, 2012). Oftentimes, these characteristics of movement caused by shape and structure of the costume itself that made the actor inside have difficulty to move. However, in several cases, the costume is well designed, so that, while it still seems wobbly and unstable, the Yuru-chara can move swiftly.

\section{Sound}

In some cases, voice is use to enrich the character interaction. Yuru-chara interact with audience in physical world to build engagement to the character.

c) Visibility

Not all of Yuru-chara live up to expectation, if the visibility of Yuru-chara is not continuously maintained through appearance and interaction on events, or social media presence they are likely to be readily forgotten. Based on the data, in many cases, regional Yuru-chara often lost their fans after two or three years due their low visibility. 
This fact suggests that Yuru-chara itself should be considered as a brand that need to be managed and maintained. Designing a brand does not stop on creating its identity, it must be followed by creating a strategic touchpoint where public can see and interact with the brand (Wheeler, 2017). Research show how Kumamon succeed by continuously maintained and managed not by a single organization, but by involving all city stake holder (Soltani et al., 2017). The royalty free strategy brings Kumamoto citizen to work together maintaining Kumamon's popularity.

\subsection{Principle of City Branding}

In designing city branding there are two kinds of goal need to be addressed. First is related to the economic benefit for the city. City branding builds a city's personality and uniqueness to helps attracting visitors, funds and residents; moreover it is also contributing to diverse economic benefits (Paliaga et al., 2010). Branding should be based on a clear set of values and beliefs with a clear purpose for the strategy to be effective and in return beneficial for the city (Jojic, 2018).

Another goal of city branding is related to the social benefit for the city. The value of a city brand can also encompass agendas of community development, reinforcing local character, enhancing citizen's attachment to their own city, and even perhaps reducing social exclusion. Cartoon characters, including promotional characters, are positively associated with consumer product recall and attitudes toward advertised product (Esmaeilpour \& Nashtaee, 2020).

In Yuru-Chara, the playfulness and cuteness of mascots helps to release tension between companies or authorities and the general public, mascots become characters designed for public relations for government agencies, events, and local goods, especially when in the form of clothes (Suter, 2016). From the field study done in Tokyo, Kyoto and Osaka, it is found that by Yuru-chara serve as a friendly representation of the city which can lead to the increasing of citizen attachment to their city. By using Yuru-chara local values/ character also could be well delivered and understandable by public. As investigation of the Kumamon and Sukjai mascots on destination branding, reserach indicated that according to the proposed framework, Kumamon has shown all three elements of the framework: 1) promoting destination identity and personality, 2) creating differentiation or the location and 3) having strong stakeholder involvement (Wattanacharoensil et al., 2020). Meanwhile, another study showed that there are five distinct functions mascots can carry out for their destinations: mascots as place identity markers, cultural constructs, bonding tools, social engagement tools, and information carriers (Radomskaya \& Pearce, 2020).

\subsection{Related Research}

There are several researches have been done to study Yuru-chara phenomena in Japan particularly in socio-cultural and socio-economical context. One of notable study that show the role of Yuru-chara in supporting local economy through an effective city branding (Soltani et al., 2017) and also the history and roots of Yuru-chara in Japanese culture (Occhi, 2010). Another research explain utilization of Yuru-chara as marketing 
tool in Japan (Occhi, 2012). There is a research which emphasize on design analysis, but it is only cover the visual aspect of the design and extract the Kansei factors from the characters' appearances and classify the characters within the factor space (Inoue \& Fujisaki, 2018). Our study tries to cover all of design aspect related to Yuru-chara. The research described in this article focusing on the design aspect of Yuru-chara.

\section{RESEARCH METHOD}

The goal of this research is to develop a design framework for creating an effective mascot character as supporting tool for city branding. To reach that goal, this research is conducted using Design Research Methodology (DRM) which is consist of four stages (Blessing \& Chakrabarti, 2009):

1) Clarification

In this stage, criteria to measure the success of proposed design framework is determined. For this research, the proposed framework is measured by two criteria:

a. Understandability

The framework should be understandable and could be performed effectively by character/ mascot designer in the design process. Evaluation by designers after experiment is performed to measure this aspect.

b. Usefulness

By following the framework, designer should be able to create a mascot design that is useful for city branding. In this case, since Yuru-chara design is used as reference, so design created using the framework should achieve the appearance quality of Yuru-Chara.

As explained before, the quality of Yuru-chara design is argued as one of key factor in successful city branding in Japan. This quality come from representation of the word 'Yurui' that could be translated as loose, gentle, or laidback. The design should evoke these kinds of feeling in the mind of its target audience, while it is also should be attractive and engaging. Second criteria for the design is to achieve the goal of city branding for governments, a city branding has four objectives, those are community development, reinforcing local character, enhancing citizen's attachment to their city, and increasing social cohesion. The design created by the framework should be able to help fulfilling these objectives.

\section{2) Descriptive Study I}

Goal of the descriptive study is to get foundation for the framework which is achieved both from theoretical and field study. The theoretical study in this research cover the field of mascot/ character design, yuru-chara design, and city branding. The field study was done in Tokyo, Chiba, Kyoto, and Osaka to observe and analyze The Yuru-chara design and phenomena in those areas. Particularly in Osaka, the observation was conducted in the 2018 Yuru-chara Grandprix at Hanazono where data of 30 distinguished Yuru-chara were gathered. To get better understanding on the Yuru-chara design practice in Japan, an interview with Mitsuru Sugaya, an expert of Manga and Character Design from In Kyoto Seika University was conducted during the field study. 


\section{3) Prescriptive Study}

In prescriptive study, proposed framework is developed based on foundation that has been specified in the previous stage. Then, an experiment is performed to test the framework. In this research, the experiment is done by involving three teams of character designer, that are asked to design mascot character for certain city in Indonesia as case of study using the proposed framework. However, there is limitation for the experiment. The design only developed as scaled mockup/ model. Therefore, the design only can be review based on its visual impression

\section{4) Descriptive Study II}

In this stage, the framework is evaluated. There are three type of evaluation performed in this research. First, evaluation for understandability of the framework. This evaluation done through group discussion with designers that is involved in the experiment. Second, evaluation for usefulness of the framework that relates to the quality of the design. It is performed based on review from the design expert, in this research two design expert is involved. Third, evaluation for usefulness of the framework that relates to city branding goals. It is performed based on review from two city branding expert.

\section{RESULT AND DISCUSSION}

\subsection{Proposed Framework}

Our proposed framework consists of four stages of process:

1) Specifying message

The message should bring positive impression of the city and represent local uniqueness. It could be anything related to the city such local animal, food, beverages, special sites, nature, arts, idiom, and so on. The message also should encourage positive attitude.

\section{2) Naming}

Naming is derived from the specified message, it is created through wordplay, combining two or three word represent the local uniqueness. The naming should be sound local, unique, distinctive memorable, and pleasant to hear.

3) Designing

Design aspects in this framework is classified into two categories, physical appearance and expression.

a. Physical appearance. There are several rules for physical appearance of the mascot design such as 1 to 3 head tall proportion; simplified, edgeless, and babylike shape; emphasizing some unique features; distinctive silhouette; consideration of costume ergonomic; and use of soft material.

b. Expression. Expression is derived from the positive attitude specified in the message. The expression consists of movement and sound. As explained before, the movement of the mascot should be unstable, and awkward, the sound should be heard pleasant, cute, and authentic. 
4) Maintaining Visibility

Maintaining visibility is important factor for success of the mascot. The visibility is created and maintained through media presence; merchandise; direct and mediated interaction.

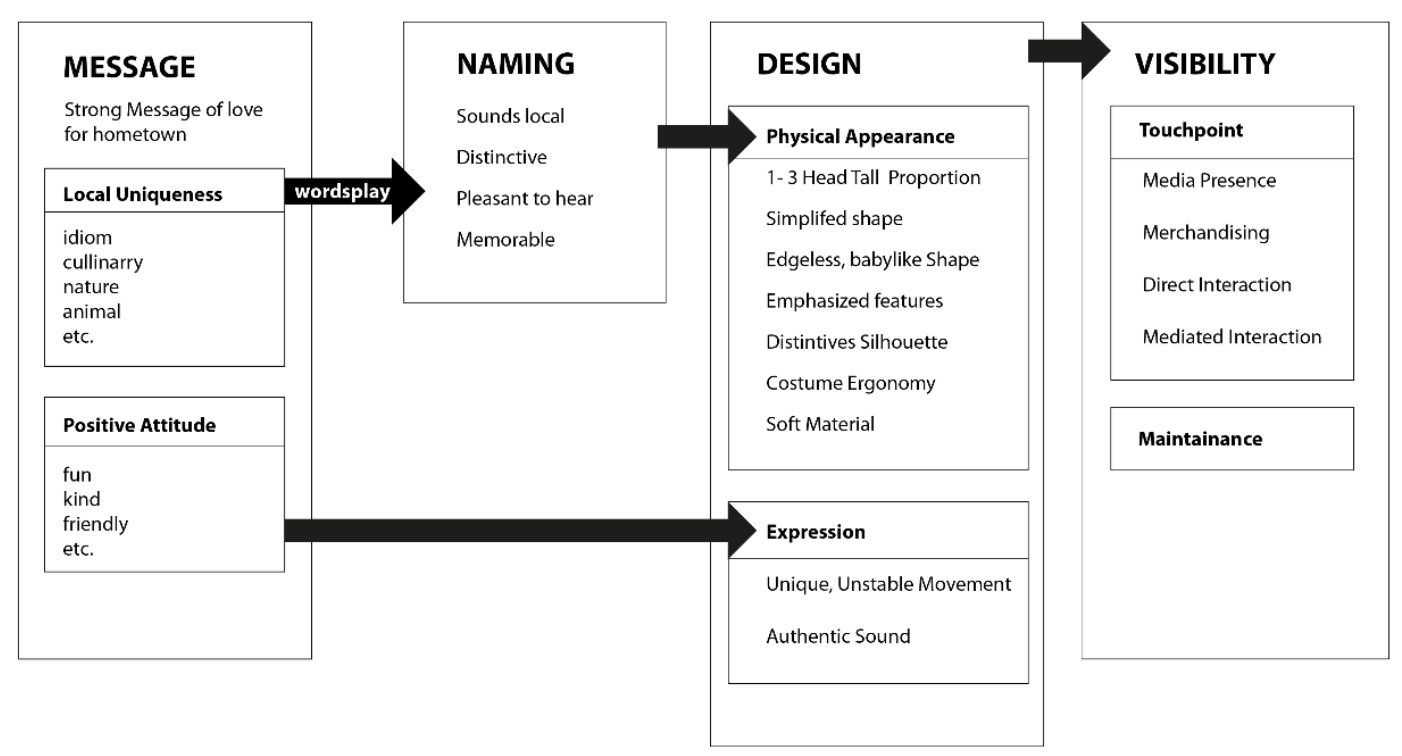

Figure 3 The proposed design framework

\subsection{Design Experiment}

In this research, the experiment focuses on physical appearance in design phase. The output is limited on 1: 8 scale mock up. The experiment is performed by 3 teams of designer.

First team designs mascot of Raja Ampat as their case study. Raja Ampat is an Island in Papua, Indonesia. It is famous for beautiful diving spots. The designers are Hanifiana Kartikasari, Samantha T. Sitompul, and Indria Dewani. Their mascot named Wobbolo, it is combination from word "Wobegong" an endemic shark of Raja Ampat, Papua, and "Molo" mean dive in Papuan Language. The design took a stylized shape of Wobegong shark, it wears a crown as a symbol of King which is translation of word Raja of Raja Ampat, and scuba diving google to emphasize diving activity (see Fig.4). The mascot proportion is 2,5 head tall with short arms and legs. 


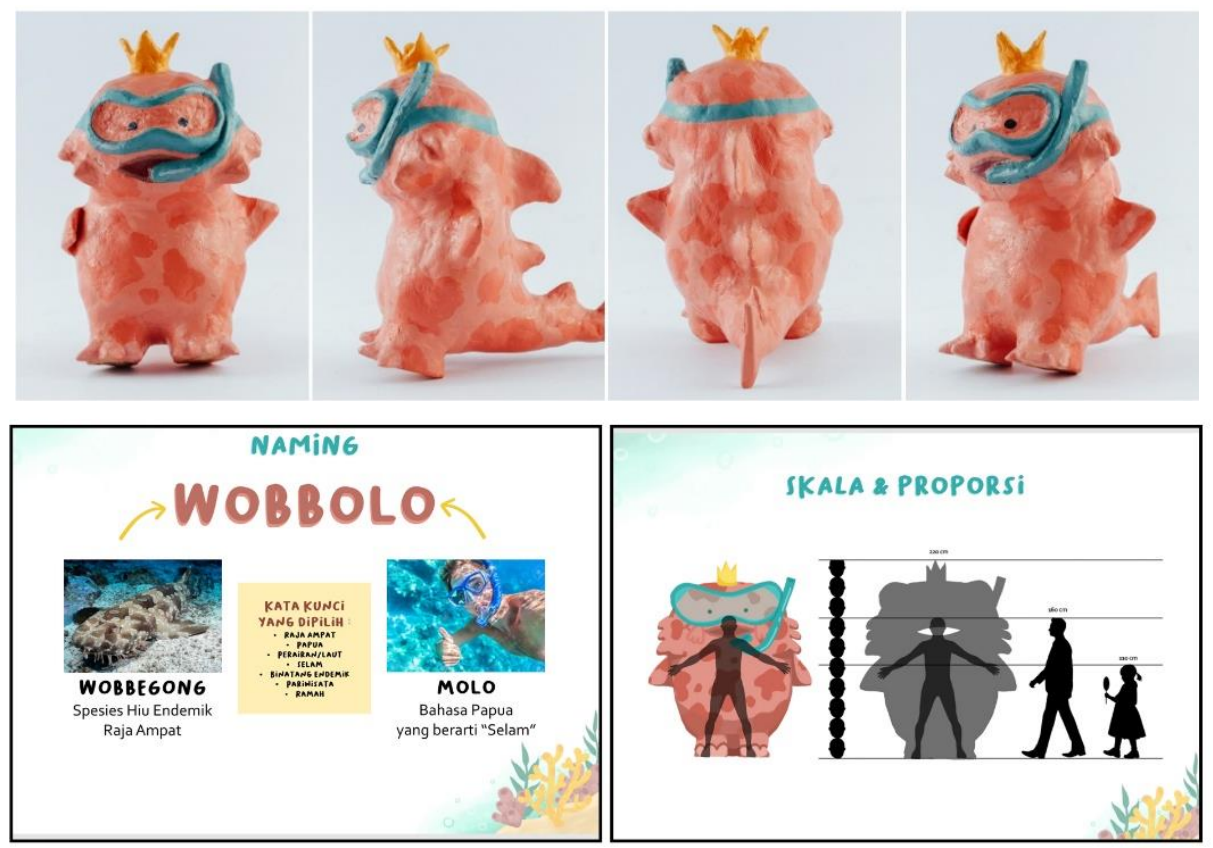

Figure 4 Design Experiment I: Wobbolo Character [Source: Author's documentation]

Second team designs mascot of Bunaken. Bunaken is National Marine Park in North Sulawesi of Indonesia. The designers are Farisa Rizki, Rizqiandini A. B., and Nabila Nindya. The Mascot named Buncaka, it is combination of words Bunaken, and "Cangkalang", the Indonesian word for Skipjack Tuna. The design took stylized shape of Cangkalang fish. It wears scuba diving google beach shirt, and slipper; resembles appearance of a tourist in Bunaken (see Fig.5). The mascot propostion is 3 head tall.

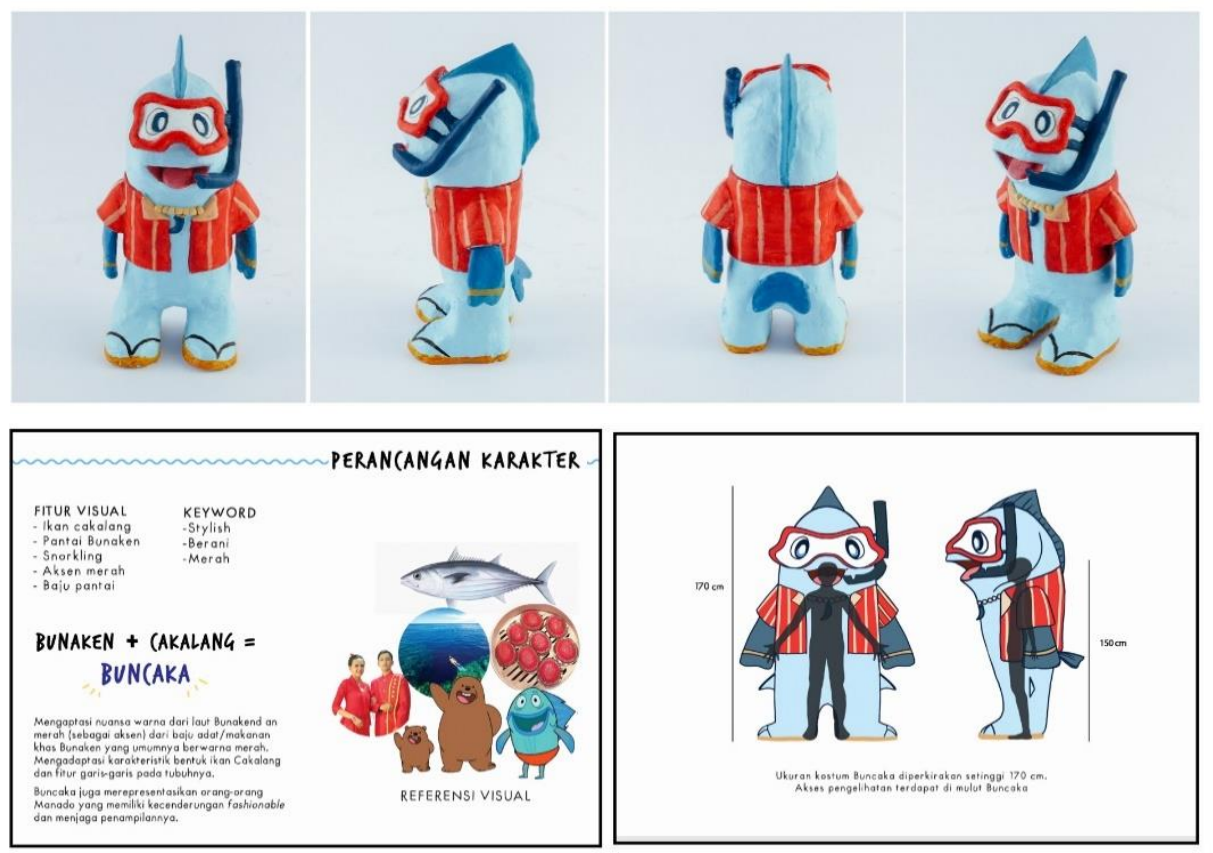

Figure 5 Design Experiment II: Buncaka Character [Source: Author's documentation] 
Third team designs mascot of Garut city. Garut is a city in West Java. It is famous for sheep leather craft, food, and its beautiful nature. The designers are Luh Tassya Nindyapratama, Qisthi Ariqah, and Sara Melati Sijabat. The mascot named Dodombe, it is combination of words "Dodol", a famous sweet from Garut, and "Embe", a Sundanese word for sheep. The design took shape of a sheep, while it faces and horn covered by textured resemble to textured of Dodol sweets. The mascot proportion is 2 head tall, with very short arms.

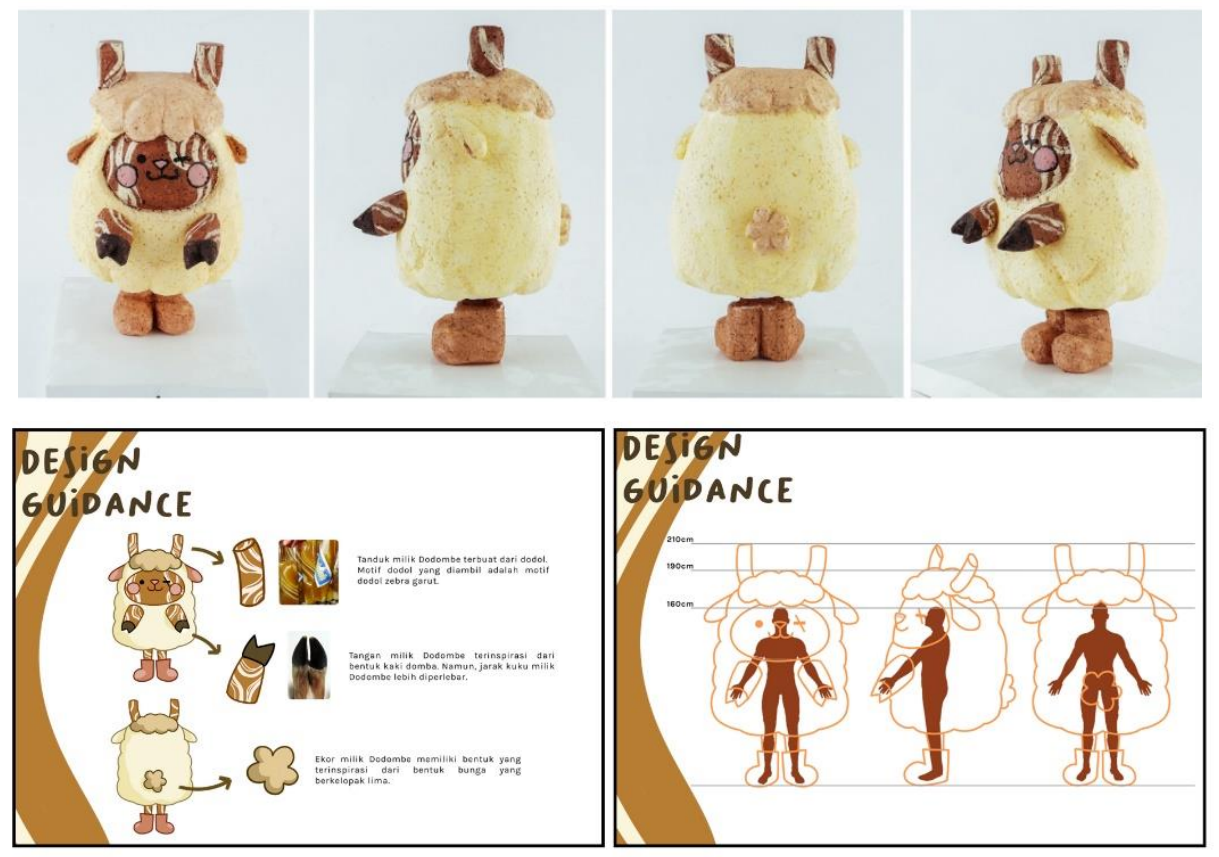

Figure 6 Design Experiment III: Dodombe Character [Source: Author's documentation]

\subsection{Evaluation of Understandability}

After performing the design experiment, each team of designers are asked to discussed their experience in a guided group discussion. Based on that discussion, it is found that the framework is quite understandable. However, building an idea from a wordplay is a new approach for the designers. Since they are not citizen of the place which is given as case study, most of them have difficulty to find a perfect name for their mascot that sound local to the place. The designers suggest that a field research to empathize or to gain familiarity to local culture and language is needed.

It is also found that designer have difficulty to design an ergonomic shape without experimenting with 3D figure or costume. To achieve the ergonomic shape, they were only assuming by scale measurement of human figure.

\subsection{Evaluation of Usefulness}

First thing that is evaluated is the usefulness for achieving preferable design appearance. Evaluation of the design's appearance is done by two-character design experts using heuristic method. The designs are assessed based on its conformity to design principles 
commonly used in character design practice. Yurui characteristic as the design manner also used as one of parameter in the evaluation.

As the result, it is concluded that on the design aspect, the proposed framework succeeded to achieved preferable character design which has yurui quality. As mentioned, Nittono proposed there is dual aspects of experiencing kawaii - a positive emotion both with biological basis but also with cultural determinants. In this case we proposed cultural determinant that align with Indonesia's culture (Nittono, 2016). The framework ensures each character design has distinct contour or silhouette. It is important principle to make the character noticeable and easy to memorize. Due some emphasized feature, the character seems appealing. Each personality and uniqueness could be presented well. Shape, proportion of its face and body ensure the character to have yurui quality.

Second aspect that is evaluated is the usefulness for branding purpose. This evaluation is performed by two branding experts, also by heuristic method. From the evaluation, it is found that the framework has some weakness to fulfill its function as supporting tool for branding. Align to past research that showed city branding is being developed in the direction of citizen participation and sharing, not only by expertise judgement (Yu \& Kim, 2020).

Although the achieved design is acceptable, it could not serve as strong representation of the places. From the concept offered by the designers, it can be seen that there is weak attachment to the places. The weakness can be traced to the research done by designers to develop their idea. There are lack in-depth research in the process regarding the object or places that used as case study for the branding.

The absent of in-depth research is a typical in Yuru-chara design process as in many cases it is designed by non-professional. Nevertheless, reflecting on the successful cases of Yuru-chara such as Kumamon, a proper design process which includes an in-depth research is necessary.

\section{CONCLUSION}

The proposed method, which is consist of four phases: (1) specifying message, (2) creating naming, (3) designing, (4) creating and maintaining visibility, is able to create a preferable mascot design that has yurui quality. The design result is attractive and appealing for audience. However, for branding purpose it has a weakness, particularly in the absent of in-depth research at process. So, as recommendation an in-depth research in design process regarding the places as objects for branding is a must. The research has to be done for defining proper message as basis for the design idea.

\section{ACKNOWLEDGEMENT}

This project was funded by The Japan-Related Research Grant program from The Sumitomo Foundation. Therefore, the authors gratefully acknowledge The Sumitomo Foundation for their support. 


\section{REFERENCES}

Blessing, L. T. M., \& Chakrabarti, A. (2009). A Design Research Methodology. Springer Dordrecht Heidelberg.

Esmaeilpour, F., \& Nashtaee, M. S. (2020). Stereotyping and advertising characters/mascots. In Food Advertising and Childhood Obesity (p. 13).

Inoue, H., \& Fujisaki, Y. (2018). Impression space analysis of local mascot characters for regional promotion. Journal of Advanced Computational Intelligence and Intelligent Informatics.

Jojic, S. (2018). City Branding and the Tourist Gaze: City Branding for Tourism Development. European Journal of Social Science Education and Research, $5(3)$.

Nakasato, Y., \& Tanaka, T. (2017). Analysis and prediction of "Yuru-Chara" mascot popularity using visual and auditory features. IEEE International Conference on Multimedia \& Expo Workshops (ICMEW), 489-494.

Nittono, H. (2016). The two-layer model of 'kawaii': A behavioural science framework for understanding kawaii and cuteness. East Asian Journal of Popular Culture.

Occhi, D. J. (2010). Consuming Kyara Characters Anthropomorphization and Marketing in Contemporary Japan. Comparative Culture, the Journal of Miyazaki International College, 15, 78-87. https://meilib.repo.nii.ac.jp/?action=pages_view_main\&active_action=rep ository_view_main_item_detail\&item_id=119\&item_no=1\&page_id=24\&bl ock_id=45

Occhi, D. J. (2012). Wobbly aesthetics, performance, and message comparing Japanese kyara with their anthropomorphic forebears. Asian Ethnology, Volume 71(1), 09-132. https://asianethnology.org/downloads/ae/pdf/a1741.pdf

Paliaga, M., Franjic, Z., \& Strunje, Z. (2010). Methodology of valuation of cities' brands. Economic Research, 23(2), 102-111.

Radomskaya, V., \& Pearce, P. L. (2020). Adding character: The role of destination mascots in tourism development. Tourism Management.

Sakamoto, M. (2017). Exploring tactile perceptual dimensions using materials associated with sensory vocabulary. Frontiers in Psychology, 8.

Soltani, A., Pieters, J. G., Young, J. O., \& Zhaohong, S. (2017). Exploring City Branding Strategies and Its Impacts on Local Tourism Success. Asia Pacific Journal of Tourism Research, 23(1).

Suter, J. R. (2016). Who Is Hikonyan? The Phenomenon of Japanese Yuru-Chara. Sociology Study, 6(12), 775-782.

Wattanacharoensil, W., Kantamara, S., \& Muangasame, K. (2020). An investigation of the Kumamon and Sukjai mascots on destination branding. Journal of Place Management and Development.

Wheeler, A. (2017). Designing Brand Identity: An Essential Guide for The Whole Branding Team 5th Edition. John Wiley \& Sons.

Yu, E., \& Kim, J. (2020). The relationship between self-city brand connection, city brand experience, and city brand ambassadors. Sustainability (Switzerland). 